Int. J. Electrochem. Sci., 11 (2016) $9891-9901$

\title{
A Glucose Biosensor Based on Glucose Oxidase enzyme and ZnO Nanoparticles Modified Carbon Paste Electrode
}

\author{
Ali Shamsazar ${ }^{1, *}$, Fatemeh Shamsazar ${ }^{2}$, Asadollah Asadi ${ }^{3}$, Saeed Rezaei-zarchi ${ }^{4}$ \\ ${ }^{1}$ Department of Biology, Payam-e-Noor University, Tehran, Iran. \\ ${ }^{2}$ Department of Chemistry, Faculty of Science, Azad University, Ardabil, Iran. \\ ${ }^{3}$ Department of Biology, faculty of Science, University of Mohagheghe Ardabili, Ardabil, Iran. \\ ${ }^{4}$ Department of Biology, Payam-e-Noor University, Yazd, Iran. \\ *E-mail: Ali.Shamsazar@yahoo.com
}

doi: $10.20964 / 2016.12 .33$

Received: 19 August 2016 / Accepted: 29 September 2016 / Published: 10 November 2016

\begin{abstract}
In this study, modified carbon paste electrode (CPE) with zinc oxide ( $\mathrm{ZnO}$ ) nanoparticles used for designing a glucose oxidase enzymatic biosensor to investigation of its electrochemical behavior, and determination of glucose concentration. The size and morphology of synthesized $\mathrm{ZnO}$ metal oxide nanoparticles evaluated via chemistry technique like scanning electron microscopy (SEM) and X-ray diffraction (XRD). A pair of clear and stable peaks in PBS ( $0.1 \mathrm{M}, \mathrm{pH}=7)$ obtained for the direct transfer of electrons from GOD to modified electrode with $-340 \mathrm{mV}$ and $-385 \mathrm{mV}$ respectively as oxidation and reduction potentials. The enzymatic biosensor exhibited a linear response to the $\beta-\mathrm{D}(+)$ glucose cancentration range from $40 \mu \mathrm{M}$ to $380 \mu \mathrm{M}$ with limit of detection equal to $8 \mu \mathrm{M}$ in a signal to noise ratio of 3 . Here, the designed $\mathrm{GOD} / \mathrm{ZnO} / \mathrm{CPE}$ electrochemical biosensor showed high stability and efficiency for glucose sensing.
\end{abstract}

Keywords: Biosensor, Glucose Oxidase, Zinc Oxide nanoparticles, Carbon Paste electrode

\section{FULL TEXT}

(C) 2016 The Authors. Published by ESG (www.electrochemsci.org). This article is an open access article distributed under the terms and conditions of the Creative Commons Attribution license (http://creativecommons.org/licenses/by/4.0/). 